\title{
Intra-Quranic connections in Sunni and Shi'i tafsirs: a meeting point or another area of contestation?
}

\section{Izza Rohman}

Faculty of Education, Universitas Muhammad iyah Prof. Dr. HAMKA (UHAMKA)

Email:izza.rohman@uhamka.ac.id

\begin{abstract}
This study seeks to shed light on how a celebrated interpretive approach to the Quran considered to be most objective is taken by interpreters from different theological settings. It takes a closer look at how the principle of tafsir al-Qur'ān bi al-Qur'ân (interpretation of the Quran by the Quran) is employed by al-Shanqiti in his Aḍ̛wā' al-Bayān and al-Tabataba'i in his al-Mizān, taking their interpretation of ahl al-bayt as a main case in point. Noticing how their differences in this issue can be associated with their respective Sunni and Shi'i backgrounds, this study finds a number of areas where both modern exegetes - and other exegetes most likely - might be influenced by any creeping theological preference in their pursuit of objectivity and openness to the text.
\end{abstract}

Kajian ini bermaksud menelaah bagaimana sebuah pendekatan penafsiran alQur'an yang dianggap paling objektif diterapkan oleh para mufasir dari latar belakang aliran teologi yang berbeda. Bagaimana prinsip menafsirkan al-Qur'an dengan al-Qur'an diaplikasikan oleh al-Shanqiti dalam tafsirnya, Aḍ̛ā̄'al-Bayān, dan al-Tabataba'i dalam tafsirnya, al-Mizān, dilihat lebih saksama terutama dengan mengambil contoh penafsiran mereka tentang ahlulbait. Mencermati bagaimana 
perbedaan mereka dalam menafsirkan cakupan ahlul bait bisa dikaitkan dengan latar belakang Sunni dan Syiah mereka, kajian ini menemukan sejumlah ranah di mana kedua mufasir modern ini - dan sepertinya juga mufasir yang lain - bisa saja dipengaruhi oleh kecenderungan teologis ketika mencoba menjaga objektivitas dan keterbukaan terhadap teks al-Qur'an.

Keywords: Quranic hermeneutics; Sunni-Shi'i dialog; al-Shanqiti'alTabataba'i; Ahl al-bayt

\section{Introduction}

Is it possible to arrive at objective (and original) meaning of the Quranic text? This question has raised a debate among modern Muslim intellectuals who pursue renewed approaches to the Quran. Fazlur Rahman, Aisha 'Abd al-Rahman Bint al-Shati', Nurcholish Madjid, Mohammed Abed al-Jabiri, and Nasr Hamid Abu Zayd - among others - arethose who evidently believe in the possibility of finding or discovering the (most) objective meaning, ${ }^{1}$ while Hassan Hanafi, Farid Esack, Abdul Karim Soroush, Mohamad Mojtahed Shabestari and Muhammad Shahrour are among the proponents of the notion of partiality of any interpretation. ${ }^{2}$

${ }^{1}$ For studies which examine their hermeneutics and support this conclusion, read Yudian Wahyudi, The Slogan "Back to the Qur'an and the Sunna": A Comparative Study of the Responses of Hasan Hanafi, Muh\}ammad 'Ābid al-Jābiri and NurcholishMadjid, a Ph.D. dissertation at the Institute of Islamic Studies, McGill University, 2002, 207-308; Abdul Mustaqim, Epistemologi Tafsir Kontemporer, Yogyakarta: LKiS, 2010, 115-330; Yusuf Rahman, The Hermeneutical Theory of Nasr Hamid Abu Zayd: An Analytical Study of His Method of Interpreting the Qur'an, a Ph.D. dissertation at the Institute of Islamic Studies, McGill University, 2001;Sahiron Syamsuddin, An Examination of Bint al-Shati"s Method of Interpreting the Qur'an, an M.A. thesis at the Institute of Islamic Studies, McGill University, 1998.

${ }^{2}$ For studies which examine their hermeneutics and support this conclusion, read YudianWahyudi, The Slogan "Back to the Qur'an and the Sunna", 207-308; KatajunAmirpur, "The Changing Approach to the Text: Iranian Scholars and the Qur'an", Middle Eastern Studies 41, No. 3, 2005: 337-350; FarzinVahdat, "Post-revolutionary Islamic Modernity in Iran: The Intersubjective Hermeneutics of Mohamad Mojtahed Shabestari", in SuhaTaji-Farouki (ed.), Modern Muslim Inte/lectuals and the Qur'an, London: Oxford University Press, 2004, 193-223; Abdul Mustaqim, Epistemologi Tafsir Kontemporer, 115-330; Andreas Christmann, "'The Form is Permanent, but the Content Moves': the Quranic Text and Its Interpretation(s) in Mohamad Shahrour's al-Kitäb wa al-Qur'ān", in SuhaTaji-Farouki (ed.), Modern Muslim Intellectuals and the Qur'an, 263-295. 
Inside but sometimes also outside this debate, there have been modern quests for "valid" and "objective" interpretive approaches to the Quran, mostly evident in continued efforts to free the text from perceived non-Quranic superimposed ideas and other texts - including the bulk of previous Quranic exegeses as well as hadith texts - so as to avoid what so-called "tendentious interpretation" or what Nasr Abu Zayd calls (ideological)"coloration" (talwin). Such efforts have been a common strategy of modern scholars to delegitimize not only many of previous exegeses (predominantly the ones categorized as tafsir bi alra'y)but also some of contemporary approaches which tend to be very functionalist.

Arguably the most central of these quests is an idea interchangeably called as to be faithful to Quranic worldview, to treat the Quran as a unity, ${ }^{3}$ to make the Quran as a criterion for any interpretation, to regard the Quran itself as the best guide to it, and to interpret the Quran with the Quran itself (tafsir al-Qur'ān bi al-Qur'ān). This idea is shared - though differently applied for different purposes - by modern textualists as well as many of contextualists, and even functionalists. The idea is applied both in the modern style of thematic Qur'an interpretation and the classical chained Qur'an commentary format. It is an idea usually built upon a classical concept al-Qur'ân yufassiru ba'duhu ba'dan (Quranic parts interpret oneanother) or istantiq al-Qur'ān (let the Quran speak), and a belief that it is the best method of interpretation which might entail the highest level of authenticity. Amir Islahi, Muhammad al-Amin al-Shanqiti, Muhammad Husayn al-Tabataba'i, Fazlur

${ }^{3}$ For an extensive review of Muslim scholars' ideas on the unity of the Qur'an, see Amir FaisholFath, The Unity of al-Qur'an, Jakarta: Pustaka al-Kautsar, 2011, previously a dissertation at the Islamabad International Islamic University entitled, Nazariyat al-Wih\}dah al-Qur'âniyah 'inda 'Ulamā' al-Muslimīn wa Dawruhā fi al-Fikr al-Islāmī. 
Rahman, Bint al-Shati', Muhammad Baqir al-Sadr, Sa'id Hawwa, Muhammad Shahrour - and the list can still go on - areamong modern exegetes whose hermeneutics is principally, though not exclusively, based on this idea. ${ }^{4}$

While whether or not the application of such an idea could be truly impartial or un-ideological remains a (largely philosophical) question to answer, those scholarly efforts have revealed a large number of what is supposed to be intra-Quranic connections and parallels. These achievements, however, have not yet received much attention from contemporary researchers.

\section{The most acclaimed way of interpretation}

The most oft-quoted scholar in great favor of the idea is arguably Ibn Taymiyah. In his Muqaddimah fi Ușül al-Tafsir, with regard to ways of interpreting the Quran, firstly he states, "The best method in it [tafsir] is that the Quran be interpreted by the Quran." ${ }^{5}$ This suggestion has been echoed by many scholars, some of whom exactly repeat his words or at least use his expressions, "așahh al-țruq" (the most correct method)and "ahsan turuq al-tafsir" (the best way of interpre-

\footnotetext{
${ }^{4}$ For studies which examine their works in Quranic hermeneutics and support this conclusion, read Mustansir Mir, Coherence in the Qur'an: A Study of Islahi's Concept of Nazm in Tadabbur-i Qur'an, Indianapolis: American Trust Publications, 1986; 'Adnan Al Shalash, al-'Allāmah al-Shanqịti Mufassiran: Dirāsah Manhajīyah fi Tafsirihi al-Musammā Aựwā' al-Bayān fi Ị̇āh al-Qurāan bi alQur'ān, 2005; Louis Abraham Medoff, Ijtihad and Renewal in Quranic Hermeneutics: An Analysis on Muhammad Husayn Tabātabāîs al-Mizān fiTafsir al-Qur'ān, a dissertation at the University of California, Berkeley, 2007; Abdul Mustaqim, Epistemologi Tafsir Kontemporer, Sahiron Syamsuddin, An Examination of Bint al-Shati"s Method of Interpreting the Qur'an; Sahiron Syamsuddin, "The Qur'an in Syria: Muhammad Shahrur's Inner-Quranic Exegetical Method", in Khaleel Mohammed and Andrew Rippin (eds.), Coming to Terms with the Qur'an, North Haledon: Islamic Publications International, 2008, 267-283.

${ }^{5} \mathrm{Abd}$ al-Halim ibn Taymiyah, Muqaddimah fi Ușūl al-Tafsirr, Beirut: Dār Ibn Ḥazm, 1997, 84. The same statement could also be found in his al-Tafsïr al-Kabïr, Beirut: Dār al-Kutub al-'Ilmìyah, n.d., vol. 2, 231.
} 
tation), to identify the method. ${ }^{6}$

Similarly, other scholars variably refer to this method as "aqrab alțuruq ilā al-șidq wa al-șawāb" (the closest method to truthfulness and correctness), "'min ablagh al-tafäsïr" (among the most reliable interpretation), "' ashraf anwā' al-tafsir wa ajalluhä" (the most reputable and highly regarded interpretation), "aqdam al-turuq al-ma'thürah" (the oldest inherited method of interpretation), ${ }^{10}$ part of (together with tafsir bi al-ma'thūr al-ṣahịh) "așaḥh țuruq al-tafsir wa ahsanuhā wa aslamuhā min al-inhirāf wa al-i'wijäj" (the most correct method of interpretation as well as the best and the safest of it from any deviation or divergence), ${ }^{11}$ "aqwā anwā' al-tafsir"(the strongest type of interpretation), ${ }^{12 "}$ ahamm al-khuțuwāt al-manhajīyah li al-tafsir" (the most important methodological step in interpretation) or "khuțuwwah asāsiyah li altafsir" (a fundamental step in interpretation) or "ahamm khuțwāt al-tafsir wa awwaluha" (the most important and first step in interpretation $),{ }^{13}$ and the best choice among available alternatives of interpretation, ${ }^{14}$ or the first necessary step to take on in interpreting

\footnotetext{
${ }^{6}$ See for instance Isma'il ibn Kathir, Tafšir al-Qurann al-'Ažim,Cairo: Mu'assasah Qurțūbah, 2000,vol. 1, 6; Muhammad ibn 'Abd Allah al-Zarkashi, al-Burhān fi 'Ulüm al-Qurân, Cairo: Dār al-

Turāth, 1984, vol. 2, 175;Muhammad Abdel Haleem, Understanding the Qur'an: Themes and Style, London: I.B. Tauris, 2011, 161.

${ }^{7}$ Fakhr al-Din al-Razi, Mafätị al-Ghayb, Beirut: Dār al-Fikr, n.d., vol. 10, 42.

8Ibn Qayyim al-Jawziyah, al-Tibyān fi Aqsām al-Qur'ān, Mu'assasat al-Risālah, 1416 AH, 185.

'Muhammad al-Amin al-Shanqiti, Aḍ̛wā' al-Bayān fi Ị̇āḥ al-Qur'ān bi al-Qur'ān, Mecca: Dār 'Ālam al-Fawā'id, $1426 \mathrm{AH}$, vol. 1, 8.

${ }^{10}$ Muhammad Husayn al-Tabataba'i, al-Mizān fiTafsir al-Qur'ān, Beirut: Mu'assasat al-A'lami li al-Mațbū'āt, 1973, vol. 1,14.

${ }^{11}$ Tahir Mahmud Muhammad Ya'qub, Asbāb al-Khața' fi al-Tafsir: Dirāsah Ta'șiliyah,Cairo: Dār Ibn al-Jawzi, $1425 \mathrm{AH}, 49,91$.

${ }^{12}$ Khalid 'Uthman al-Sabt, Qawā'id al-Tafsir: Jam'anwaDirāsah, Dār Ibn 'Affān, n.d., vol. 1, 109. Tahir Mahmud, Asbāb al-Khața' fi al-Tafsir, 91.

${ }^{13}$ Salah 'Abd al-Fattah al-Khalidi, Ta'rïf al-Dārisin bi Manāhij al-Mufassirinn,Damascus: Dār alQalam, 2008, 147, 150.

${ }^{14}$ For instance, IbnJuza, al-Tashïl li 'Ulūm al-Tanzill, vol. 1, 9.
} 
the Quran. ${ }^{15}$

In fact, many have implied that there has been a wide consensus (ijmā)among Muslim scholars on that this method is not only a must in interpreting the Quran but also the first thing to do or even the best, most authoritative and highest procedure of interpretation. ${ }^{16}$ It is even hard to find any scholar who challenges such an assumption. Its importance is simply regarded as "cannot be seriously challenged."17 One could even find an assertion that this method "has to be followed and accepted without any doubt or any reserve."18

If one bears in mind the debate over whether interpretation is always partial or not, such a statement would then be a question: if interpreting the Quran by the Quran should be considered to be the best or the most valid method of interpretation, can it be a method from which an interpreter of the Quran seeks help to minimize or avoid biased projections onto the text? Put differently, one might ask: can it be a method which leads an interpreter away from any ideological coloration?

The answer might for the most part support the objectivists' argument that a certain adequate hermeneutical method can help minimize biases or even arrive at objective meaning (often assumed as located within the text), or otherwise by and large confirm the premise of those like so-called "functionalists" (or liberative theologians) that interpretation is always partial, so does meaning (assumed as always in process). And yet, the answer might also be disputed by, or seen differently from, both perspectives.

15Jalal al-Din al-Suyuti, al-Itqān fi 'Ulūm al-Qur'ān, Cairo: Dār al-H\{adith, 2006, vol. 4, 455; Khalid 'Abd al-Rahman al-'Akk, Ușūl al-Tafsirir wa Qawā'iduhu, Beirut: Dār al-Nafā'is, 1986,79.

${ }^{16} \mathrm{Al}-\mathrm{Sh}$ anqiti, Aựwā' al-Bayān, 8;al-'Akk, Ușūl al-Tafsir, 79; Abdullah Saeed, The Qur'an: An Introduction, London \& New York: Routledge, 2008, 179.

${ }^{17}$ Abdel Haleem, Understanding the Qur'an..., 165.

${ }^{18}$ Tahir Mahmud, Asbāb al-Khatata' fi al-Tafsir..., 91. 
Why interpreting the Quran by the Quran comes to be the best method and how we should employ it are perhaps questions more immediately in mind while reading Ibn Taymiyah's statement abovementioned. However, rather than arguing why it be the best and how to put it into practice, Ibn Taymiyah straight away turns to the issue of the possibility or necessity of applying the method in his next two sentences. He states, "Where the Quran sums up (a point), the same point is elaborated in another place. What is briefly mentioned in one place is explained in detail in another place."19 Such a notion oft-referred to as (part of) the concept of the Quran being self-explanatory (al-Qur'ān yufassiru ba'ḍuhu ba'ḍan) - which has also been over and over again repeated by classical and contemporary scholars - implies that there are intra-Quranic connections and parallels, i.e. internal links between Quranic verses in a certain sura and other verses in other suras or in another distant part of the sura, or between a Quranic verse and the surrounding verses (al-sābiq wa al-lāhiq), to which any interpreter should pay much attention. ${ }^{20}$ Nevertheless, given there has been only very limited examples available from interpreters of the Quran in early days (including the Prophet himself), ${ }^{21}$ interpreters are readily faced by a question to answer: which verses explain/ interpret which verses - a problem which requires them to perform a

${ }^{19}$ Ibn Taymiyah, Muqaddimah fi Ușūl al-Tafsir, 84.Interestingly, these statements are the only brief (but often quoted) explanation on the importance of interpreting the Qur'an by the Qur'an available in the book. After these sentences, he straight away starts an extended discussion on another topic related to interpretation through Sunnah and the sayings of the salaf.

${ }^{20}$ Intra-Quranic parallels have been recognized in 'ulūm al-Qur'ân through the concept of nazāi'ir (usually paired with wujūh). For a summary of this concept, see Fahd ibn 'Abd al-Rahman al-Rumi, Buhūth fi Ușūl al-Tafsir wa Manāhijihi, Maktabat al-Tawbah, n.d.

${ }^{21}$ There have been only two examples narrated from the Prophet mentioned by al-Suyuti while listing interpretations narrated from the Prophet in the last part of al-Itqān, vol. 4, 488534. The first is al-An'ām [6]: 82 which is explained by Luqmān [31]: 13, and the second is Ibrāhim [14]: 17 which is explained by Muhammad [40]: 15 and al-Kahf [18]: 29. 
careful ijtihād ("scholarly creative endeavour"). In fact, ijtihād might not only give rise to differences but also be incorrect. ${ }^{22}$ Keeping in mind the previous issue of partiality, one can therefore pose another question: are those links pursued through ijtihād something often (if not always) agreed upon or merely another area of contestation among Qur'an interpreters? For one thing, if the links serve as another contested area, then our previous question regarding the potentials of interpreting the Quran by the Quran to lead an interpreter to impartial interpretation might easily be answered.

Another way to formulate the preceding question is: to what extent can this interpretive method be a meeting point for Muslims from different schools of thought?

\section{Two Sunni and Shi'i tafsirs most intensively applying the method}

This study seeks to answer the last question so as to provide some insights to answer earlier questions. In doing so, this study will primarily take the cases of two modern Qur'an exegeses which have not only been among the most intensive full-scale sequential tafsirs in terms of the application of the methodology of interpreting the Quran by the Quran to date, but also written by two 'allämahs of the same period coming from two very different theological schools each of which has been largely critical to the other throughout history.

The two exegeses are al-Mizān fi Tafsir al-Qur'ān by an Iranian Shi'i scholar al-'Allāmah Muhammad Husayn al-Tabataba'i (1904-1981) and Aḍwā' al-Bayān fi Ị̇āḥ al-Qur'ān bi al-Qur'ān by a Mauritanian-born Saudi Sunni/Salafi scholar al-'Allāmah Muhammad al-Amin al-Shanqiti (1907-1973). ${ }^{23}$ On the one hand, both tafsirs are arguably based on

\footnotetext{
${ }^{22}$ Khalid al-Sabt, Qawā'id al-Tafsir, vol. 1, 107, 109; Tahir Mahmud, Asbāb al-Khata', 96.

${ }^{23}$ There have been several studies on these two works and their authors' methodology of Qur'an interpretation. Among earlier standard studies on al-Tabataba'i's al-Mizān most relevant
} 
the application of tadabbur and istintāq (al-Tabataba'i's key concepts of inner-Quranic hermeneutics respectively meaning "contemplation" and "allowing the Quran speak for itself") or ị̣āh al-Qur'ân bi al-Qurān ("explaining the Quran by the Quran", al-Shanqiti's term) in a more serious and fashionable manner. ${ }^{24}$ On the other hand, one could expect that the very fact that these works are authored by a Shi'i and a (Salafi) Sunni in particular might shed light on the existence - orthe absence - ofa kind of consensus among Qur'an interpreters pertaining to "which verses explain which verses" and thereby reveal a meeting point - or merely another contested field - between the two groups.

To provide a comprehensive answer to the above question might require a more thorough and prolonged, extensive study- while this study can at best be its preliminary part. Here I would like to highlight some arguments one might find from closely looking at a few ex-

\footnotetext{
to this study are: 'Ali al-Awsi, al-Ṭabātabāîwa Manhajuhu fi Tafsirihi al-Mizān,1985; Louis Abraham Medoff, Ijtihad and Renewal in Quranic Hermeneutics, and Mohammad Hossein Mokhtari, The Exegesis of Tabatabaei and the Hermeneutics of Hirsch: A Comparative Study,a Ph.D. dissertation at the Durham University, 2007.On al-Shanqiti's tafsir and methodology, there is:'Adnan Al Shalash, al-'Allāmah al-Shanqït\}̧ Mufassiran: Dirāsah Manhajīyah fi Tafsirihi al-Musammā Ad\}wā' al-Bayān fi Ị̇āh al-Qur'ān bi al-Qur'ān, which is among the most recent standard studies on his tafsir. There have been also many MA theses submitted in Middle Eastern universities discussing al-Shanqiti's work and approach. Different from earlier relevant studies, this study will exclusively examine the method of interpreting the Qur'an with the Qur'an (tafsir al-Qur'ân bi alQur'ân) - sometimes referred to as "cross-referential hermeneutics" or "inner-Quranic exegetical method" - asconceived and practiced by al-Tabataba'i and al-Shanqiti in their respective commentaries. On this method of tafsir, a recent and more relevant work is Muhsin Hamid Mutayri, Tafsir al-Qur'ān bi al-Qur'ān: Ta'șil wa Taqwìm, Riyad: Dār al-Tadmuriyah, 2011.

${ }^{24}$ Based on some statistical comparisons between both tafsirs and other tafsirs recognized as employing the method, my previous study finds that al-Shanqiti's Aḍ̛ā' al-Bayān is arguably the one most dependent upon the method, followed by al-Qasimi's Mahāsin al-Ta'wïl, al-Tabataba'i's al-Mizān, Ibn Kathir's Tafsir al-Qur'ān al-'Ażim, and al-Razi's Mafätịh al-Ghayb. A more qualitative analysis on these tafsirs, however, would reveal that al-Tabataba'i's al-Mizān is among the ones most deeply highlight the connection between parts of the Qur'an - similar to Medoff's conclusion that al-Tabataba'i employed the methodology of istintāq in an unprecedented way in terms of intensity and intensiveness. Hence, it might be argued that both tafsirs are the ones intensively applying the method of interpreting the Qur'an with the Qur'an.
} 
amples of interpretation in both tafsirs. In this regard, given the fact that many differences between the two theological schools are mainly related to the question of "who", 25 I would take the case of interpretation ofahl al-bayt (mainly in al-Ahzāb [33]: 33, known as "tathïr [purification] verse") and - to a lesser extent - alladhina an'amta 'alayhim (mainly in al-Fātihahah [1]: 7) to discuss both tafsirs.

\section{A meeting point in tafsir between Sunni and Shi'i?}

The fact that the notion to interpret the Quran with the Quran itself is supported and implemented by both Sunni and Shi'i scholars might be areason to argue that this method is a potential meeting point in tafsir between Shi'a and Sunni. Both al-Tabataba'i and al-Shanqiti are aware of the importance of this method. Al-Tabataba'i wrote al-Mizān to demonstrate a methodology of istintāq (allowing the Quran speak for itself), i.e. by interpreting the Quran with the Quran. In his view, this way of interprationis the oldest, inherited method of interpretation(aqdam al-turuq al-ma'thürah), which has been unfortunately largely neglected (matrūk ghayr mas/ūk). This method is a valid way - even the most valid one - to interpret the Quran. It is an authentic Quranic hermeneutics based on correct principles. Al-Tabataba'i is critical to classical and contemporary tafsirs much filled with the interpreters' personal opinion or too dependent on using riwāyāt (narrated traditions), rather than using the Quran to elaborate the meaning of its verses. The best choice to interpret the Quran, to al-Tabataba'i, is by tadabbur (contemplation) to a point that we find Quranic verses are self-interpreting. Quranic verses explain and support each other (yantiqu ba'ḍhu ba'ḍan

${ }^{25}$ Sunni and Shi'a are disputing, for instance, who the legitimate caliph after the Prophet was (Abu Bakr or 'Ali), who the role modelsmore important to Muslim religiosity after the Prophet are (Sahāāba or Ahl al-Bayt), etc. 
wa yashhadu ba'duhu ba'dan).The immediate advantage of applying this methodology is that we will never interpret a verse contrary to its zāhir (the obvious, immediate meaning of the text).

Avoiding to interpret the Quran contrary to its zāhir is also important for al-Shanqiti, who seemed to have been much influenced by Ibn Taymiyah's thought - either in tafsir or salafismin general.His work, Ad wā̄'al-Bayān is firstly and mainly aimed at explaining the Quran with the Quran (ị̣̂āh al-Qur'ān bi al-Qur'ān), a method he calls "the most reputable and highly regarded interpretation" (ashraf an wā' al-tafsir wa ajalluha $)^{26}$ and included in the title of his tafsir. Some studies on his tafsir finds that its strength lies in the application of tafsir al-Qurān bi alQur'ān. ${ }^{27}$

If one looks at intra-Quranic connections revealed by both exegetes resulted from their application of the method, the argument that it is a common ground in tafsir between Sunni and Shi'a might be affirmed. Intra-Quranic connections in these two tafsirs seems to be, most of the time, complementary, rather than contradictory. They are even sometimes identical. Below are some rather purposively selected examples of intra-Quranic connections both scholars agree upon, along with a list of intra-Quranic connections mentioned by only one of the two.

${ }^{26}$ This claim seems to be based on an assumption that no one is more knowledgeable on the meaning of Allah's sayings than Allah Himself. See al-Shanqiți, Aḍ̛wā' al-Bayān..., 8.

${ }^{27}$ For instance, Ahmad Lafi Falah al-Matiri, "Dalālat al-Siyāq al-Qur'ānifi Tafsir Aḍwā' al-Bayān li al-'Allāmah al-Shanqịți: Dirāsah Mawḍūīiyah Tahliliyahan M.A. thesis at the University of Jordania, 2007, 40. 


\begin{tabular}{|c|c|c|c|}
\hline \multirow{2}{*}{$\begin{array}{l}\text { Interpreted Quranic } \\
\text { word/phrase/verse }\end{array}$} & \multicolumn{3}{|c|}{ "Interpreting" Quranic verses } \\
\hline & Both mention & $\begin{array}{l}\text { Mentioned only } \\
\text { by al-Tabataba'i }\end{array}$ & $\begin{array}{l}\text { Mentioned only } \\
\text { by al-Shanqiti }\end{array}$ \\
\hline $\begin{array}{l}\text { A/-Rahmān } \\
{[1: 1 \text { or1: } 3]}\end{array}$ & $20: 5$ & 19: 75 & $\begin{array}{l}\text { 25: } 59 \\
67: 19 \\
55: 1-3\end{array}$ \\
\hline $\begin{array}{l}\text { Al-Rahim } \\
\text { [1: } 1 \text { or } 1: 3]\end{array}$ & $\begin{array}{l}33: 43 \\
9: 117\end{array}$ & - & - \\
\hline $\begin{array}{l}\text { Al-ladhina an'amta } \\
\text { 'alayhim } \\
\text { [1: 7] }\end{array}$ & 4: 69 & $\begin{array}{l}\text { 4: } 65-6 \\
57: 19 \\
\text { 58: } 11 \\
\text { 5: } 55\end{array}$ & - \\
\hline 16: $99-100$ & $\begin{array}{l}15: 42 \\
36: 60\end{array}$ & - & $\begin{array}{c}38: 82-3 \\
17: 65 \\
34: 20-1 \\
14: 22 \\
19: 44 \\
4: 76\end{array}$ \\
\hline $\begin{array}{l}\text { Al-Qawl } \\
{[36: 7]}\end{array}$ & $\begin{array}{c}\text { 38: } 84-5 \\
37: 31 \\
39: 71 \\
10: 96\end{array}$ & $\begin{array}{l}15: 42-3 \\
16: 106-8\end{array}$ & $\begin{array}{c}\text { 41: } 25 \\
28: 63 \\
36: 70 \\
11: 118-9 \\
32: 13\end{array}$ \\
\hline $\begin{array}{l}\text { Wa naktubu ma } \\
\text { qaddamū wa } \\
\text { atsarahum wa kull } \\
\text { shay' ahșaynā hu fi } \\
\text { imām mubin } \\
\text { [36: 12] }\end{array}$ & $\begin{array}{l}45: 29 \\
17: 13\end{array}$ & $\begin{array}{c}6: 59 \\
45: 28\end{array}$ & $\begin{array}{c}\text { 43: } 80 \\
\text { 17: } 14 \\
\text { 18: } 49 \\
\text { 50: } 18 \\
\text { 16: } 25 \\
\text { 29: } 13 \\
\text { 75: } 13 \\
\text { 82: } 5 \\
\text { 9: } 121 \\
\text { 72: } 28 \\
6: 38 \\
\end{array}$ \\
\hline
\end{tabular}

This does not mean, however, that both exegetes have always had the same understanding about what these intra-Quranic connections they agree upon could mean - or not mean. Their interpretation on alladhina an'amta 'alayhim (those on whom God has bestowed His grace) is an example. Both argue that the people God has bestowed favor are those mentioned in al-Nisā' [4]: 69, consisting of al-nabiyyūn, 
al-șiddiqūn, al-shuhadā' and al-șālihūun. Nevertheless, for al-Shanqiti, this verse justifies the legitimacy of the caliphate of Abu Bakr, a companion the Prophet called al-șiddiq.On the other hand, while discussing the verse, al-Tabataba'I points out that al-Mā'idah [5]: 55, a verse believed to be a sanction of the virtue and the right of walàyah (leadership) that 'Ali ibn Abi Talib had, might explain the meaning of what he calls așhāb al-șirāt al-mustaqïm (those on the straight path - upon whom God has bestowed favor, that is suggested in the end of al-Nisā' [4]: 69 as the best of friends).

In addition, the fact that intra-Quranic connections both exegetes find are very often complementary and sometimes just the same, does not mean that both are necessarily free from theological biases when connecting - or not connecting - acertain part of the Quran to its another part. A theological bias, I would argue, can still possibly dictate an interpreter's choice of which part of the Quran he would refer to or not refer to - whilediscussing a certain Quranic verse, phrase or word. Al-Tabataba'i's and al-Shanqiti's discussions on the meaning ofahl al-bayt, areperhaps a good example.

\section{The scope of Ahl al-Bayt debated}

Who ahl al-bayt consists of has been subject to varying interpretations - even among scholars within the same sectarian background. There has been, however, a quite noticeable difference between sectarian lines.Most of Shi'i scholars believe that it refers specifically to ahl al-kisā' (People of the Cloak), namely 'Ali ibn Abi Talib, his wife Fatimah, their sons al-Hasan and al-Husayn, in addition to the Prophet himself. Some of them also include Imāms (from the lineage of al-Hasan and alHusayn) in the definition. On the other hand, many Sunni scholars believe that it refers to $a h l a l-k i s \bar{a}^{\prime}$ as well as the wives of the Prophet. 
Some of them include their descendants as well, some even also include the families of the Prophet's relatives, such as 'Aqil, Ja'far and 'Abbas, as well as their descendants, while a few of them just include the Prophet's wives(usually in addition to the Prophet himself).

Even though both al-Tabataba'i and al-Shanqiti agree upon the significance and benefits of interpreting the Quran with the Quran and their commentaries are in many cases complementary, their discussions on what the term ahl al-bayt (literally: People of the House) mentioned in al-Ahzāb [33]: 33 implies to some extent might have shownboth their preference over an objectivist interpretive approachand their theological partiality at the same time.

Al-Tabataba'i starts with an argument that basically the term could not exclusively comprise the wives of the Prophet Muhammad to finally conclude that the term mentioned in the verse could have definitely been meant to just include five persons: the Prophet himself, his cousin and son-in-law 'Ali, his daughter Fatimah, and his grandsons al-Hasan and al-Husayn - and none of his wives. Meanwhile, al-Shanqiti starts with an argument against those who see that the term ahl al-bayt under discussion does not include the wives of the Prophet Muhammad to finally conclude that it is incorrect to say that the term excludes the Prophet's wives as much as to say that it only includes these wives.

It is noticeable that what becomes al-Shanqiti's starting point is what becomes al-Tabataba'i's ending point-which is also a conclusion made by most ofShi'i scholars, such as'Ali ibn Ibrahim al-Qummi in Tafsir alQur'ān, al-Tusi in al-Tibyān,al-Tabarsi in Majma' al-Bayān, al-Fayd alKashani in al-Safi,including Zaydi exegetes like Furat al-Kufi, al-Habari,and al-A'qam in their respective tafsirs.On the other hand, what becomes al-Tabataba'i's starting point is part of what becomes al-Shanqiti's ending point - which is also a position of some Sunni scholars, such as al- 
Maturidi in Ta'wilāt Ahl al-Sunnah, Abu Hayyan in al-Baḥr al-Muḥit, Ibn Kathir in Tafsir al-Qur'ān al-'Ažim, al-Tha'alabi in al-Jawāhir al-Hisān, Ibn 'Adil in al-Lubāb, and al-Qasimi in Mahāsin al-Ta'will, a stance clearer than that of most of Sunni exegetes who mostly just mention the differences (among the Sahabah or later generations) in defining the scope of ahl al-bayt, like al-Tabari in Jāmi' al-Bayān, al-Tabrani in alTafsir al-Kabïr, al-Tha'labi in al-Kashf wa al-Bayān, al-Mawardi in alNukat wa al-'Uyūn, al-Baghawi in Ma'ālim al-Tanzil, Ibn 'Atiyah in alMuharrar al-Wajiz, Ibn al-Jawzi in Zād al-Masir, and al-Suyuti in al-Durr al-Manthūr. Most of Sunni tafsirs cite three to four different viewsregarding the scope of ahl al-bayt: 1 ) that it just consists of the Prophet and the household of 'Ali (ahl al-kisā'), 2) that it just consists of the Prophet and his wives, 3) that it comprises both groups, and 4) that it also includes other families from Banū Mutțalib, in addition to the previous two groups.

For al-Shanqiti, the fact that the verses before and after the verse where the term is mentioned (al-Ahzāb [33]: 28-32, 34), as well as the beginning of the verse itself (al-Ahzāb [33]: 33), undoubtedly address the Prophet's wives is a clear indication (qarinah) that they are - at least - part of ahl al-bayt cited in the end of the verse - though it could include other individualsas well, as it is clear from so many hadiths that 'Ali, Fatimah, al-Hasan and al-Husayn are called ahl al-bayt. Al-Shanqiti's attention to the surrounding verses regarded as a relevant context in which ahl al-bayt should be understood, is consistent with the principle of interpreting the Quran with the Quran he would like to employ.

Al-Tabataba'i is aware of such an argument focused on siyāq (the context of discourse). Nonetheless, by demonstrating a rational analysis on the content of the last part of the verse, innamā yuridu Allāh liyudhhiba 'ankum al-rijs ahl al-bayt wa yutahhirakum tathiran, and the 
content of the preceding verses (as well as the beginning of the verse 33), a typical way of tadabbur in his tafsir, and asserting that all traditions related to sabab nuzül of the last part of the verse do not mention neither its surrounding verses nor its preceding part, so it might be assumed that this part must have been revealed to the Prophet independently, he seeks to convince his readers that the term ahl al-bayt in the last part of the verse is not related to the Prophet's wives. The term under discussion, according to al-Tabataba'i, could not be understood as exclusively implying the Prophet's wives, nor encompassing the Prophet and his wives, norboth the five members of ahl al-kisā'and his wives. If the term is understood as merely comprising the Prophet's wives, the use of 'ankum, which is a masculine plural pronoun, to refer to ahl al-bayt in the verse that already uses kunna, a feminine plural pronoun, in its beginning to address the Prophet's wives, and the availability of riwāyāt that explain otherwise (that ahl al-bayt means family members or relatives other than the Prophet's wives), might be adequate reasons to reject such an interpretation. Meanwhile, if the term is understood as encompassing the Prophet's wives and others, there might be a bit contradiction in meaning one can find with deeper contemplation. The commandments of the verses given to the wives seem to contradict the protectedness implied in the purification verse.

While al-Tabataba'i focuses on examining logical consequences of understanding ahl al-bayt as solely consisting of the Prophet's wives or consisting of them and others, al-Shanqiti focuses on the plausibility of the use of the term to mean - partly or exclusively - wives, both in the Quran and in general Arabic usage more broadly. That wives are categorized in what so-called ahl al-bayt,al-Shanqiti argues, is confirmed by another verse mentioning the word ahl al-bayt, i.e. Hūd [11]: 73 which uses the word to refer to the wife of Ibrahim, Sara. This connec- 
tion between the only Quranic verses mentioning the word - i.e. alAḥāb [33]: 33 and Hūd [11]: 73 - is, however, absent in al-Tabataba'i's analysis. Al-Shanqiti further argues that it is common in Arabic that (even) "a wife" is termed $a h /$ and thereby referred to with a masculine plural pronoun. This is also affirmed by some Quranic verses, for instance Țāhā [20]: 10 and al-Naml [27]: 7 which refer to the wife of Musa. Again, these intra-Quranic linguistic connections are absent in alTabataba'i's analysis.

Nonetheless, al-Tabataba'i supports his argument on the "independency" of the second part of the verse from the first part and earlier verses with implying that this is something we can find in other parts of the Quran. For him, the relationship between the second part (innama yuridu Allāh...) and the first part (waqarna fi buyūtikunna ...) is just like that between a part in the middle of al-Mā'idah [5]: 3 (al-yawm ya'isa alladhina kafarū ...) and its beginning part (hurrimat 'alaykum al-maytah ...). It seems that he seeks to imply that there is nothing strange in the shift of addressee in the Quran - an argument one can also find in al-Tabarsi's discussion of the purification verse in Majma' al-Bayān.

Al-Tabataba'i's argument ultimately relies very much upon riwāyātan approach that in his methodology should be used,rather secondary, to support understanding derived from tadabbur and istintāq. It is mainly based on the availability of many riwāyāts that exlusively mention 'Ali, Fatimah, al-Hasan and al-Husayn as the Prophet's ahl bayt, and makeno mention of his wives (and even some riwāyāts clearly implythat none of the wives of the Prophet is part of ahl al-bayt), that al-Tabataba'i rejects the view that $a h l$ al-baytalso includes the wives, and accepts the view that it comprisesonly the five persons of ahl al-kisā'.

On the other hand, al-Shanqiti stresses the fact that among these many riwāyāts, there are a number of riwāyāts which imply that the 
wives of the Prophet were included in ahl al-bayt. This might strengthen the argument that to include the Prophet's wives in the definition is defensible.However, al-Shanqiti brings no discussion on the fact that thereare more riwāyāts state otherwise, which al-Tabataba'i' uses to support his opposing argument.

\section{Concluding remarks}

Let the Quran speak generally means making links between its parts. In this case, interpreters would very much pay attention to perceived intra-Quranic connections. These connections can be found in many Quranic commentaries, particularly by those relying on the importance of a methodology of interpreting the Quran by the Quran. There are many common connections, at least mutually complementary, in those tafsirs, even among tafsirs across sectarian lines, as we have seen its instances in al-Shanqiti's and al-Tabataba'i's tafsirs. However, there are a number of areas where interpreters of the Quran seem to be compelled to be apart.

First, the understanding of intra-Quranic connections. When different interpreters discover the same intra-Quranic connections, they might differ in understanding those connections. Even though bothagree on the connectedness between al-Fātihah [1]: 7 and al-Nisā' [4]: 69 for instance, how al-Tabataba'i and al-Shanqiti understand these connected verses seem to be in part shaped by their theological affiliation so each find in the verses a legitimacy of their respective sectarian belief.

Second, the connectedness of some verses in order. Interpreters might possibly differ in understanding the connectedness - and disconnectedness - between a verse or a part of a verse with its neighbouring verses. This difference might also be sometimes influenced by their theological belief. As we have seen, al-Shanqiti and al-Tabataba'i dis- 
agree on the interrelatedness between "the verse of purification" and the verses nearby.

Third, the choice to connect - or not to connect -a Quranic word, phrase or verse being interpreted to remote parts of the Quran. This choice could possibly sometimes be dictated by theological preference. As discussed above, al-Shanqiti connects the purification verse to the other verse mentioning the word ahl al-bayt, while al-Tabataba'i does not. This also contributes to how each differently interprets the word.

Fourth, the choice on to which partsof the Quran one relates a Quranic word, phrase or verse and on what context the relationship is built. This choice could possibly sometimes shaped by theological inclination as well.While al-Shanqiti chooses to take Hūd [11]: 73, Ṭāhā [20]: 10 and al-Naml [27]: 7 into account when discussing al-Ahyāb [33]: 33 to justifythatthe Quran uses the word ahl and ahl al-baytto refer to a Prophet's wife and to clarify the Arabic grammar in the verse, al-Ṭabāțabā'i brings al-Mā'idah [5]: 3 into discussion to explain the disconnectedness of the second part of al-Ahzāb [33]: 33 from nearby verses.

Fifth, the decision to rely upon sound riwāyāt to clarify the exact meaning of a Quranic word, phrase or verse while interpreting the Quran based on the Quran itself. This decision could possibly be directed by theological preference. While al-Shanqiti is more inclined to sufficiently rely upon the Quran to holdthat the Prophet's wives were included in ahl al-bayt and rely upon riwāyāt to hold that ahl al-baytalso comprised the household of 'Ali, al-Tabataba'i seems to much rely on riwāyāt to embrace a view that ahl al-baytmentioned in the purification verse is intended to specifically refer to the five personalities constituting ahl al-kisā'. 
With these areas, any attempt to arrive at objective meaning of the Quranic text might become harder and harder - if it is considered possible, and any claim of the superiority of tafsir al-Qur'ān bi al-Qur'ān might have to be accepted with a great caution. Nevertheless, despite its potential to be contested by Muslims, this most acclaimed method of tafsir could possibly provide a common ground to dialog Muslim differences as long as any theological bias is acknowledged and minimized. Also, the fact that any theological partiality could creep into how this method is applied, needs not to make us fail to remember that there are many not theologically-debated verses in the Quran.

\section{Bibliography}

al-'Akk, Khalid 'Abd al-Rahman. Ușūl al-Tafsìr wa Qawā'iduhu. Beirut: Dār al-Nafā'is, 1986.

al-Awsi, 'Ali.al-Ṭabātabā'î wa Manhajuhu fi Tafsirihi al-Mizān,1985.

al-Jawziyah, Ibn Qayyim.al-Tibyān fi Aqsām al-Qur'ān. Mu'assasat alRisālah, $1416 \mathrm{AH}$.

al-Khalidi, Salah 'Abd al-Fattah. Ta'rïf al-Dārisin bi Manāhij al-Mufassirīn.

Damascus: Dār al-Qalam, 2008.

al-Matiri, Ahmad Lafi Falah.Dalālat al-Siyāq al-Qur'ānī fi Tafsìr Aḍwā'alBayān li al-'Allāmah al-Shanqịtị: Dirāsah Mawdựilyah Tahlililiyah. University of Jordania, 2007.

al-Razi, Fakhr al-Din. Mafätiḥ al-Ghayb. Beirut: Dār al-Fikr, n.d.

al-Rumi, Fahd ibn 'Abd al-Rahman. Buhūuth fi Ușūl al-Tafsir wa Manāhijihi. Maktabat al-Tawbah, n.d.

al-Sabt, Khalid 'Uthman. Qawā'id al-Tafsirr: Jam'an wa Dirāsah. Dār Ibn 'Affān, n.d. 
al-Shanqiti, Muhammad al-Amin. Aḍ̛ā' al-Bayān fi Ị̇āḥ al-Qur'ān bi alQur'ān. Mecca: Dār 'Ālam al-Fawā'id, 1426 AH.

al-Suyuti,Jalal al-Din.al-Itqān fi 'Ulūm al-Qur'ān. Cairo: Dār al-Ḥadith, 2006.

al-Tabataba'i,Muhammad Husayn.al-Mizān fiTafsìr al-Qur'ān. Beirut: Mu'assasat al-A'lami li al-Mațū'āt, 1973.

al-Zarkashi, Muhammad ibn 'Abd Allah. al-Burhān fi 'Ulūm al-Qur'ān. Cairo: Dār al-Turāth, 1984.

Amirpur, Katajun."The Changing Approach to the Text: Iranian Scholars and the Quran", Middle Eastern Studies 41, No. 3 (2005): 337-350.

Christmann, Andreas. "'The Form is Permanent, but the Content Moves': the Quranic Text and Its Interpretation(s) in Mohamad Shahrour'sal-Kitabwal-Qur'an", in SuhaTaji-Farouki (ed.), Modern Muslim Intellectuals and the Quran. London: Oxford University Press, 2004: 263-295.

Fath, Amir Faishol. The Unity of al-Qur'an. Jakarta: Pustaka al-Kautsar, 2011.

Haleem, Muhammad Abdel. Understanding the Quran: Themes and Style. London: I.B. Tauris, 2011.

Ibn Kathir, Isma'il. Tafsir al-Qur'ān al-'Aẓim. Cairo: Mu'assasah Qurțūbah, 2000.

Ibn Taymiyah, 'Abd al-Halim. al-Tafsirr al-Kabïr. Beirut: Dār al-Kutub al'Ilmiyah, n.d.

Ibn Taymiyah, 'Abd al-Halim.Muqaddimah fi Ușūl al-Tafsirr. Beirut: Dār Ibn Hazm, 1997, 84. 
Medoff, Louis Abraham. Ijtihad and Renewal in Quranic Hermeneutics: An Analysis on Muhammad Husayn Tabātabāi's al-Mizān fi Tafsir al-Qur'ān. Berkeley: University of California, 2007.

Mir, Mustansir. Coherence in the Quran: A Study of Islahi's Concept of Nazm in Tadabbur-i Qur'an. Indianapolis: American Trust Publications, 1986.

Mokhtari, Mohammad Hossein. The Exegesis of Tabatabaei and the Hermeneutics of Hirsch: A comparative study. Durham University, 2007.

Mustaqim, Abdul. EpistemologiTafsirKontemporer. Yogyakarta: LKiS, 2010.

Mutayri,Muhsin Hamid. Tafsir al-Qur'ān bi al-Qur'ān: Ta'șil wa Taqwim. Riyad: Dār al-Tadmurìyah, 2011.

Rahman, Yusuf. The Hermeneutical Theory of Nasr Hamid Abu Zayd: An Analytical Study of His Method of Interpreting the Quran. Montreal: Institute of Islamic Studies, McGill University, 2001.

Saeed, Abdullah. The Quran: An Introduction. London \& New York: Routledge, 2008.

Shalash, 'Adnan Al.al-'Allāmah al-Shanqịtị Mufassiran: Dirāsah Manhajīyah fi Tafsirihi al-Musammā Ad\}wā' al-Bayān fi Ị̇āh al-Qur'ān bi alQur'ān, 2005.

Syamsuddin, Sahiron. "The Quran in Syria: Muhammad Shahrur's Inner-Quranic Exegetical Method", in Khaleel Mohammed and Andrew Rippin (eds.). Coming to Terms with the Quran. North Haledon: Islamic Publications International, 2008: 267-283.

Syamsuddin, Sahiron.An Examination of Bint al-Shati"s Method of Interpreting the Quran. Montreal: Institute of Islamic Studies, McGill University, 1998. 
Vahdat, Farzin. "Post-revolutionary Islamic Modernity in Iran: The Intersubjective Hermeneutics of Mohamad Mojtahed Shabestari", in SuhaTaji-Farouki (ed.), Modern Muslim Intellectuals and the Quran. London: Oxford University Press, 2004: 193-223.

Wahyudi, YudianWahyudi. The Slogan "Back to the Quran and the Sunna": A Comparative Study of the Responses of Hasan Hanafi, Muhammad 'Ābid al-Jābiri and NurcholishMadjid. Montreal: Institute of Islamic Studies, McGill University, 2002.

Ya'qub, Tahir Mahmud Muhammad. Asbāb al-Khata' fi al-Tafsir: Dirāsah Ta'șiliyah.Cairo: Dār Ibn al-Jawżi, 1425 AH. 